\title{
JEWISH CHARITIES
}

On April 26, 1655, the board of directors of the Dutch West India Company wrote to Governor Stuyvesant as follows: "After many consultations, we have decided and resolved upon a certain petition made by said Portuguese Jews, that they shall have permission to sell and to trade in New Netherland and to live and remain there, provided the poor anong them shall not become a burden to the company, or to the community, but be supported by their own nation."

The records of the Department of Charities of the city of New York now show that in a Jewish population approximating 600,000 in Greater New York, in the almshouse on Blackwell's Island there are seventeen pauper Jews, of whom the majority were blind, idiotic or possessed of some peculiar defect which prevented admission to existing Jewish charitable institutions.

What is true of New York Jews is true of their co-religionists everywhere. The Jew has always cared for his own poor. During the biblical period, the wise and humane laws of the Mosaic code made the welfare of the unfortunate a civic duty and specified the manner in which assistance was to be given in order to do the least harm to the recipient. After the destruction of the Commonwealth, the common woe which followed the dispersion brought into play new forms of charitable effort to meet the need and distress occasioned by the acute poverty of the people. It is the irony of fate to say that the Jews provided for their poor during the Middle Ages and the centuries which preceded and followed them. Jewish charity was sectarian through compulsion. When every man's hand was raised against the Jew, rich or poor, it followed that any charitable provision for the latter class must of necessity be arranged by the former. And the pity of it all was that the charity of the Mosaic legislation was not narrow and sectarian. It could and did include within its scope, the "stranger" and the non-Jew. It was broadly humanitarian, having regard for the servant as well as for the master. It was a world-wide scheme of philanthropy, the like of which is not to be found to-day, since it was grounded not merely on the bases of love and pity, but on justice. The gleanings of the field were not given to the poor man as a gift, but as his due. Similarly

$$
\left[3^{89}\right]
$$


the tithes were exacted from all, rich and poor alike, in the nature of an assessment to carry out the principles of justice and righteousness on which the charity law was based.

In our modern day, under more favorable conditions and auspices, the Jew has, to some extent, reverted to the non-sectarian idea in his philanthropies. Hospitals, as a rule, supported and endowed by Jews, throw open their doors to sufferers irrespective of creed, color or nationality. Other instances could be cited of charities not medical, organized along similar lines. The free employment bureau of the United Hebrew Charities makes no distinction with its applicants. The Educational Alliance offers its clubs and classes to Jew and Gentile alike. Jewish agencies, giving material relief, or to use a better term, those which care for the needy in their own homes, in the main confine their work to beneficiaries of their faith, without, however, making any rigid distinction. On the other hand, the trend of Jewish charity has been in the direction of caring for the Jewish poor, solely through Jewish agencies, and without the intervention or co-operation of other sectarian or non-sectarian societies or institutions. Such a condition of affairs is the resultant of the compulsion of the centuries. The task which was at one time assumed of necessity has to-day become a proud duty. What in Stuyvesant's day was obligatory and mandatory, is to-day accepted as a voluntary responsibility.

To what extent and for what length of time the care of the Jewish poor may remain exclusively in Jewish hands, it is impossible to say. The question is hardly a religious one. Jewish poverty is due mainly to economic and industrial causes. It is true that religious persecution is largely at the bottom of these causes, but the condition which such persecution has produced is not to be overcome by any organization or set of organizations founded on purely religious lines. If the impoverished Jew requires the interference of his wealthier co-religionist, it is because the latter is better able to understand his needs and has a peculiar, specialized knowledge of a peculiar class of individuals. Were it possible for public charities or for nonsectarian private charities to grasp the fundamentals of Jewish poverty, to obtain that keen insight into the modes of living and thought of a heterogeneous people whose common meeting-point is their religion, an insight so necessary to bring the proper forms of relief into play, there is no reason why the paor Jew should not be the 
recipient of the charitable impulse of the entire community. The Jew's religion per se is not a factor in the solution of his physical needs. It is characteristic of his history that the greater his poverty and distress, the greater has been his religiosity and his steadfastness to his ethical and religious convictions. It is a far cry, however, to the time when the Jew will be able to lay down his selfassumed burden and delegate it to others, not only ready and willing to shoulder it, but competent to unravel the intricacies of the Jewish character, whose roots are deeply grounded in centuries of tradition. For the present the Jew must care for the Jew.

The problem of the Jewish charitable societies of the United States to-day is the problem of the care of the immigrant. As such, it passes beyond merely local lines. In some of its manifestations it is national in character and in few it has an international significance.

The fact that the large bulk of the needy Jews in the United States reside in New York is accidental, and concerns the Jews of Denver and San Francisco equally with those of the Eastern seaboard cities. Insofar the problem is a national one. Moreover, to deal intelligently with the question requires a knowledge of the immigrant's antecedents, the impelling motive which brought him to the United States, and an acquaintance with his previous environment. And here the international phase of the question comes in.

Roughly speaking, it may be said that there are no Americanborn Jewish poor. Of the I0,06I families who applied for assistance to the United Hebrew Charities of New York during its last fiscal year, 2 per cent were born in the United States. And of these the majority of heads of families were of the first generation. Jewish dependents who have an ancestry in the United States of more than two generations are practically unknown. Nor can it be stated that there have ever been enough native-born dependent Jews to make an issue, since the Stuyvesant episode. In the report of the president of the above society for the year I88I, the statement is made that during no time since the formation of the society had there been less want than during the first six months of the fiscal year just ended. It must have been gratifying for those present at the meeting to learn that after all the poor in the city had been given adequate relief, there was still in the society's treasury a comfortable balance of over $\$ 14,000$. During the following year, so large were the 
receipts of the society and so small the demands of the regular recipients, that the balance in the treasury at the end of the year had swelled to nearly $\$ 19,000$.

In the year I88I began that great wave of emigration from eastern Europe, the end of which is not yet. Driven by a relentless persecution, which endangered not only their homes but frequently their lives, thousands of Jews were compelled to flee from their homes to seek new residence on these shores. The Russo-Jewish committee which originally undertook the work of caring for these immigrants turned it over very shortly to the Hebrew Emigrant Aid Society, which came into existence in December, 188I. In one year this society spent $\$ 250,000, \$ 50,000$ less than had been spent by the United Hebrew Charities of New York in the seven years of its existence. In the first and only annual report of the Emigrant Aid Society, its president outlined as tersely as possible the efforts that had been made to provide homes and occupations for the thousands of fleeing exiles who reached these shores during the momentous summer of 1882 . In the month of July the committee spent for board and lodging alone over $\$ 1$ I,700. Of the herculean efforts of the members of the committee, of the sacrifices of time and money, the report in its modesty makes but scant mention. The full history of the Emigrant Aid Society is yet to be written.

With the gradual falling off in immigration, the Emigrant Aid Society went out of existence, and the care of the needy immigrant who remained in New York and who became impoverished after residence, reverted to the United Hebrew Charities. In I 885 immigration again began to grow heavier and continued to grow in such numbers that in the following five years over 120,000 immigrants arrived at Castle Garden. In 1890 the immigration reached the figures of $32,32 \mathrm{r}$, the largest number ever recorded up to that time.

With all that had been done, the real work of the charities was but to begin. In 1891 the religious persecution of the Russian Jews reached a climax. In the year ending September 30, 62,574 immigrants arrived at New York, of whom nearly 40,000 arrived between June and September. The entire charitable effort of the New York Jewish community was for the time directed out of the ordinary channels and applied to this monumental question of caring for the arriving Russian Jews. The Baron de Hirsch fund, instead of utilizing its income for its educational work, appropriated over \$67,- 
ooo to the United Hebrew Charities to assist in the work of the immigration bureau. Over $\$ 175,000$ was spent by the United Hebrew Charities during this year. In September of I891 it became apparent that there would be no cessation to the immigration and that much larger funds would be necessary to give anything like adequate assistance to the unfortunates who were arriving at the rate of 2,000 per week. The enthusiasm which was aroused at a banquet tendered to the late Jesse Seligman brought into existence the "Russian Transportation Fund," which added over \$9o,ooo to the revenues of the United Hebrew Charities and which was given by citizens of New York, irrespective of creed. Later in the year, a standing committee of the society, known as the Central Russian Refugees Committee, was organized and was made up of representatives of the Baron de Hirsch Fund, the Russian Transportation Fund, the United Hebrew Charities and the American Committee for Ameliorating the Condition of the Russian Exiles. The last committee was organized to secure the co-operation of relief societies in other cities, in order that the various European societies who were assisting the persecuted Russians to emigrate should thoroughly understand the attitude of the New York organization.

The year, October, I891, to September, 1892, will ever be a memorable one in the history of Russian emigration and of Jewish philanthropy; 52,134 immigrants arrived at the Barge office in that time. The treasurer of the United Hebrew Charities paid out the enormous sum of $\$ 32$ I, 3 II .05 , of which $\$ 145,200$ was spent by the Russian Refugees Committee between February and September. Like the Hebrew Emigrant Aid Society, the history of the Central Russian Refugees Committee is still to be written. At present it is included in the bald statement of a treasurer's report. Should it ever be published, it will tell a tale of devotion, of altruistic effort, of sacrifice, of noble charitable impulse unparalleled in the history of American Judaism.

Since the year I88I, fully 600,000 Jewish immigrants have arrived at the port of New York alone. Of these the bulk comprise refugees from Russian and Roumanian persecution, Austrians and Galicians. They came from countries in which many of them lived under conditions of appalling poverty. The records of the immigration burean show that from the standpoint of material wealth, these immigrants are below the average of immigrants from other Euro- 
pean countries. Due to their previous condition, a goodly percentage is illiterate. On the other hand, the number of skilled artisans and craftsmen is so large as to be distinctly noticeable. From the standpoint of dependency, it will be of interest to study to what extent this large body of immigrants has added to the dependent and delinquent classes of the communities in the United States. The only figures that are at hand are those of New York, which are higher than would be found in other cities and towns for reasons that are obvious.

In December, 1899 , the writer made a study of 1,000 families who had originally applied to the United Hebrew Charities for assistance in October, 1894. Of these I,000 applicants it was found that 602 had not applied for assistance after December, I894. Of the balance, 67 families were dependent on the society to a greater or lesser extent in January, 1899. More detailed investigation disclosed the fact that nearly all of these 67 applicants were made up of families where the wage-earner had died, leaving a widow with small children, or of respectable aged and infirm couples unable to be fully self-supporting, or of families in which the wage-earner had become incapaciated through illness. In other words, after five years over 93 per cent of the cases studied were independent of charitable interference.

While the above study was limited in its scope, and while the deduction which can be drawn from it must be accepted with reserve, it is nevertheless typical of Jewish charitable conditions. The marked feature in the care of the Jewish poor in the United States is the almost entire absence of the so-called pauper element. Even the sixty-seven families above mentioned cannot be included in this category. Widowhood is the resultant of purely natural conditions, and when it afflicts the poor mother with a family, it frequently produces a condition of dependence which has in it no characteristics of demoralization. The brightest and most hopeful chapter in the history of Jewish charity is the avidity and eagerness with which its beneficiaries, bereft of the main wage-earner, become self-supporting and independent as soon as the children are old enough to contribute to the family income.

If there is one cause more than another leading up to this condition, it is the absence of the drink evil among Jews. The instances in which drunkenness lies at the bottom of Jewish dependency are 
so infrequent that they may be ignored. Combined with the absence of this vice, there are other virtues engrafted on the Jew for centuries, all of which tend to the preservation of his self-respect and his selfesteem. Among these are the love of home, the inherent desire to preserve the purity of the family, and the remarkable eagerness which he shows for education and self-improvement. Poverty with the Jew does not spell degeneracy. He has known it too long to fear it, and even through its worst invasions, he has come forth stronger, more confident, more self-reliant. Poverty he knew in darkest Europe, where it was forced upon him. He brought it with him when he came to the United States, and under the beneficent environment which encompassed him here, he has escaped from its clutches to a large extent. The small percentage who become or remain dependent after a residence of any length in the United States are influenced by causes extraneous to the individual, and which are mainly the product of their environment. What these causes are will develop subsequently.

This detailed exposition of Jewish poverty is timely, in view of the fear that has been expressed of late, that continued Jewish immigration together with other immigration from Oriental Europe may develop potentialities harmful to American customs and thought. It is feared that pauper elements will be introduced into American life, which may become obnoxious and detrimental. A discussion of the question is outside the province of this paper. So far as the Jew is concerned, the fear is without warrant of fact. The history of the Jewish charities in the United States demonstrates nothing more forcibly than that the Jewish immigrant, be he German, Russian, Roumanian or Galician, readily adapts himself to his American environment, easily assimilates the customs and language of his adopted country, and even though he may temporarily require assistance, rapidly becomes independent of charitable interference. The immigrant Jew is frequently poverty-stricken. He is rarely a pauper, in the sense in which the word is most commonly used. He is not found in the besotted, degenerate, hopeless mass of humanity constituting the flotsam and jetsam of society, the product of generations of vice and crime and debauchery, which makes up the scum of our present civilization. Given the opportunity and the proper surroundings, the immigrant Jew will become an addition to the body politic and not a menace. 
From what has preceded, it will be comprehensible that the Jewish charities of the United States, having a special problem with which to deal, have instituted special methods for its solution. In the main, relief organizations have followed the organized methods of sister societies. In the past twenty years, new organizations of all kinds have sprung into existence to meet the demands made by the constantly increased immigration. To revert to New York, when the Central Russian Refugees Committee went out of existence in January, I893, the decrease in immigration no longer warranting its continuance, the active work of assisting the arriving immigrants devolved upon the United Hebrew Charities.

The work of this society will be cited here somewhat in extenso, since it is typical of similar Jewish organizations throughout the United States. The report of the fiscal year ending September 30, I902, shows that 10,061 individuals and families applied for assistance. Of these, 5,603 had applied for the first time. Material relief was granted to 8,$125 ; 1,270$ were found not to require assistance of this kind, and 666 were refused assistance for some cause or other. The society conducts an employment bureau which is free to employer and employee, and during the last fiscal year found employment for 5, I 12 applicants. It grants relief in kind, including groceries, clothing, shoes, furniture, etc. The extent of the society's work in this direction will be gathered from the statement that 48,802 garments and pieces of furniture were distributed last year. The annual disbursements for material relief alone amount to over $\$$ I IO,OOO per annum. Ever since its organization twenty-nine years ago, the society has endeavored to uphold the principles of organized charity. In some instances it has antedated the charity organization societies themselves. We need but mention the giving of relief in amounts adequate to make the recipient independent of further intervention on the part of the relief-giving agency, and the establishment of a graded, carefully regulated and supervised system of pensions covering if necessary a long period of years. As a rule, these pensions are given only to families where the wage-earner has died, and where, unless such provision were made, no recourse would be left, except the breaking up of the family and the commitment of the children to orphanages and similar institutions. To obviate the necessity of such commitment, the United Hebrew Charities disburses annually over $\$ 30,000$ in pensions. In the history of the society there 
is no form of relief which shows such good returns for the investment made. Families so supported do not become pauperized, since the subsidy which is granted enables the surviving parent to devote her time to the proper rearing of her children so that they may become useful and intelligent citizens. To such children the society stands in loco parentis. Dependency of this kind does not lead to degeneracy. Where the home can be preserved, where children can develop under the care of the natural guardian, there is little likelihood of dependency extending to succeeding generations. So far as the Jew at least is concerned, this fact has been too often and too amply evidenced to require further illustration.

A word may be said here on the question of adequate relief. In the revulsion which accompanied the indiscriminate almsgiving of earlier decades, the so-called organized charities which resulted therefrom frequently went to the other extreme and withheld material relief in the fear of its baneful effect on the recipient. Nothing is more characteristic of our present-day charities than the gradual return to the sound doctrine that material relief is not the end desired, but merely a means to the end, and that it must be used, if necessary, equally with other forms of relief, and must be given adequately if at all. Jewish charity has always upheld this belief. Granted dependency, and material relief in many instances follows. Its danger lies in giving it as a dole. If it must be given, let the amount of it be proportionate to the applicant's needs and not to the amount that can be obtained from a more or less charitably disposed community.

Along these lines the United Hebrew Charities frequently grants assistance, presumably as a loan, in amounts varying from $\$ 50$ to $\$ 250$. These loans are made in special cases where it is not possible to make the applicant self-supporting through the ordinary channels of employment, etc. A wage-earner who has been incapaciated through illness or injury and hence unable to follow any routine work, may still be established in some small business venture and be able to support his family. Thousands of dollars have been spent by the United Hebrew Charities along these lines with the most gratifying results-not only have beneficiaries become independent of the society, but many of them have managed to repay the loans made to them.

Of all the problems which confront the average charity organization, possibly the most perplexing is the one of the family in [397] 
which the mother must be the wage-earner. The kindergarten and the day nursery have by no means solved the problem. They are at best but makeshifts in an attempt to solve a situation which has its root in economic and industrial conditions. Again, the factory removes the mother from her sphere of influence over her children, and opens up opportunity for the growth of incorrigibility and waywardness on the part of the latter. In the hope of partially overcoming this difficulty, the United Hebrew Charities has for some years conducted a work-room for unskilled women in which the latter are taught various needle industries, in the hope that they may eventually be sufficiently accomplished to work in their own homes, and in this fashion supplement the family income. The amount of such work that can be found is limited. More and more, daily, the factory is competing with home industry to the exclusion of the latter. A study made by the society last year showed that work could be obtained for women to do at home in industries such as silk-belt making, men's and women's neckwear, garters and hose supporters, paper boxes, slip covers for the furniture trade, overgaiters and leggings, dressing sacques, hats and caps, flowers and feathers, beaded purses and other beadwork, dress shields, incandescent light mantles, embroidery and art embroidery, passementerie work, bibs. knit goods, etc. In the society's work-room the effort has been made to teach such industries to unskilled women, so as to enable them to become at least partially self-supporting.

It is needless to state that in a system as comprehensive as the United Hebrew Charities desires to be, provision has been made to alleviate distress in all its forms. Under the plan of dividing the city into districts, immediate relief can be given to emergency cases. These districts are in charge of co-operating societies known as sisterhoods, who are responisible for the condition of the poor who have been placed in their care. Each of these agencies is practically a miniature United Hebrew Charities. Not only have they organized centres for the distribution of material relief, but along the lines of a more progressive philanthropy, the sisterhoods have developed day nurseries, kindergartens, clubs and classes of various kinds, employment bureaus, mothers' meetings, and in fact have become a social centre for the poor of their neighborhoods. Since a large percentage of the distress which is met with is occasioned by illness, medical relief of all kinds has been organized. Each district 
as a rule has its physician and its nurse, and where these are not at hand, co-operation has been effected with other organizations specially equipped for such work.

In very recent years, the spread of tuberculosis among Jews has merited the earnest attention of the society, and among its other activities it has been a pioneer in developing a systematic plan for caring for such tuberculous applicants in their own homes, for whom no provision could be made in existing sanatoria. The campaign thus begun has been not only a charitable, but a social one. Not only have these unfortunates been given food, nourishment and medical care to aid them towards recovery, but in addition thereto, instruction has been given them in the rudiments of sanitation, and in the prevention of infection. It is significant that the work of the United Hebrew Charities in this field has been followed to some extent by the recently organized Committee on Tuberculosis of the Charity Organization Society. So successful have the United Hebrew Charities been in this undertaking, that it points with pride to the beneficiaries who have recovered their health and who have been made self-supporting in outdoor pursuits in such a manner that the likelihood of a recurrence of the disease has been materially lessened.

As stated before, the work of the United Hebrew Charities of New York has been cited somewhat in detail, since it illustrates the methods adopted by practically all relief agencies in the United States. The name "United Hebrew Charities" as applied to the New York organization is somewhat of a misnomer, since it does not include all Jewish charitable agencies in the city of New York. It would be more proper to speak of it as the consolidation of all the purely relief societies which existed in New York prior to 1874 . Aside from these, there are to-day hospitals, orphanages, technical schools for boys and girls, trade schools, day nurseries and kindergartens, guilds for crippled children, burial societies, loan societies, societies for maternity relief, and a goodly number of smaller organizations which have been founded by the immigrants of the last twenty years. It is estimated that there are over one thousand Jewish organizations and societies in the city of New York to-day, whose activities to a greater or lesser extent are directed along philanthropic lines. Practically all of the larger organizations, such as the hospitals, etc., work in co-operation with the United Hebrew 
Charities. It is only a question of time until even the smallest will direct its activities in consonance with the work of the central society.

In some of the other cities in the United States, where the question of the care of the poor is not so complex as in New York, closer co-operation has gone by leaps and bounds. In cities like Philadelphia, Cincinnati, Chicago, Cleveland and others, the individual societies have formed federations of charities, the purpose of the federation being to express the philanthropic impulse of the community in terms of greatest economy, the smallest amount of friction and the highest possible efficiency. In Philadelphia the federation is the common treasury. It acts as the common collection agency of all moneys and distributes them pro-rata among the various societies and institutions whose autonomy is not impaired by this method. In other cities, this plan with some slight variations is in force.

In addition to these local federations, the various societies throughout the Lnited States have joined together to form a national body known as the National Conference of Jewish Charities. At present it comprises the relief organizations of fifty-three cities. Two biennial conferences have been held and the published reports of these meetings indicate conclusively the wisdom and the necessity of founding such a national organization. The rules governing the transportation of dependents which have been in force in the National Conference of Jewish Charities since its inception, were adopted at the last meeting of the National Conference of Charities and Correction as a basis for similar rules to be recommended to the latter organization at its next meeting in Atlanta in May, I903. At the meeting of the National Conference of Jewish Charities held in Detroit in May last, the writer introduced a resolution advocating the establishment of a central bureau for the placing out and boarding out of dependent Jewish children in private homes. At that time the work of devising such a plan was delegated to the Independent Order B'nai B'rith, a fraternal Jewish order, which at present has the entire subject under discussion, and has drafted a plan which has been submitted to the various Jewish societies and institutions throughout the country.

Some idea of the extent to which Jewish charities have been developed in the United States may be gathered from the following: In practically every city and town there are benevolent societies which look after the interests of the poor in their midst. Jewish [400] 
orphan asylums are established in the cities of Atlanta, Baltimore, Boston, Brooklyn, Chicago, Cincinnati, Cleveland, Newark, N. J., New Orleans, New York, Philadelphia, Pittsburg, Rochester and San Francisco. In New York there are three institutions and in Philadelphia there are two. New York has four Jewish hospitals and Philadelphia has two. Baitimore, Chicago, Cincinnati, Denver, New Orleans and San Francisco have each one. Homes for the aged and infirm are found in most of the large cities. Similarly, educational movements along philanthropic lines are developing throughout the country. These include organizations such as the Hebrew Educational Society of Brooklyn, the Hebrew Education Society of Philadelphia, the Jewish Training School of Chicago, the Hebrew Free and Industrial School Society of St. Louis, the Hebrew Industrial School of Boston, the Clara de Hirsch Home for Working Girls, the Hebrew Technical School for Girls, the Hebrew Technical Institute and the Baron de Hirsch Trade School, the last four being situated in the city of New York. The Maxwell Street Settlement of Chicago and the Neighborhood House in St. Paul are under Jewish auspices. Cincinnati, Milwaukee and Cleveland have Jewish settlements. In New York the Educational Alliance, the largest institution of its kind in the United States, has within the past few years developed a settlement with resident workers.

Earlier in this paper reference was made to the fact that much of the Jewish dependency in the United States and in particular in the large cities is due to causes that are not inherent in the individual but are objective and not subjective; in other words, are a product of his environment. Of the million Jews in the United States nearly 600,000 resicle in the city of New York and of the latter over 50 per cent reside in one square mile of territory on the east side of the borough of Manhattan. The recent agitation in regard to tenementhouse legislation in New York is still too fresh in the minds of students of this subject to require much further mention here. It will be remarked, however, that in the campaign which was made to preserve the vital features of the present tenement-house law, the Jewish residents on the East Side of New York were a unit in demanding that no drastic changes in the law be made. Similarly at the recent municipal election, it was the citizens and voters of this same district who rose en masse and in a campaign that was startling in its uniqueness and originality, purged their neighborhood of the 
vices and immorality which existed there. And this brings us to the point at issue.

Whatever views the interested may have on this subject, it cannot be denied that there are limits to the housing of individuals in a restricted territory. Family life cannot be properly maintained without a certain amount of privacy, and one of the essentials for the procurement of the latter is a sufficiency of room. The danger to morals, which lies in overcrowding, is due primarily to the inability to carry on a natural home life. The unit of society after all is the family, and the preservation of the latter means the preservation of the social fabric. With this thought in mind, it is not difficult to understand how a people, who through the ages have been heralded as the champions of purity in the home, have through the conditions under which they live, taken on some of the attributes of their surroundings and absorbed some of the deteriorating effects of their environment. The natural concomitants of overcrowding are disease and vice and crime. The Jew's power of assimilation is proverbial. It was but natural therefore that he, along with his Christian neighbor, should be attacked in his moral fibre in the overcrowded tenements in which he lived; that he should contract diseases which were new and strange to him, and to which he had formerly not been liable. In fact his apparent immunity to tuberculosis to-day, in spite of conditions, is a medical anomaly. The wonder is that a greater percentage of the Jewish population residing in the socalled "Ghetto" of our large cities has not fallen victims to the vices and diseases which breed there. The concern of the thinking Jew lies in the fact that the percentage of Jewish vice and crime and disease as found to-day in our large cities, small as it may be, is nevertheless distinctly larger than statistics show to have been the case heretofore. To the student of affairs, there is a menace in a condition of things which on its face shows such dangerous possibilities. Referring to New York in particular, it cannot be denied that the city, through its geographical position, has peculiar limitations with respect to population which cannot be overstepped without a serious injury to the community. As a matter of fact, certain sections of the city, particularly those in which the poorer elements of the population live, have long since passed the boundaries of normal housing, and there has resulted a harvest of poverty and vice, crime and disease which are the adjuncts of such abnormal congestion. 
So far as the Jews are concerned, nothing could be more indicative of these conditions than the amount of so-called juvenile delinquency. In the House of Refuge on Randall's Island, there are over 200 Jewish boys and girls. In the Juvenile Asylum there are 230 Jewish children under sixteen years of age committed for various misdemeanors. Compared with the entire Jewish population of the city, the number is insignificant, and the ratio will probably be found to be considerably lower than that of the general population. To the Jewish philanthropist and sociologist, there is cause for alarm in these figures, because he sees that the crowded life of the streets, the lack of playgrounds and breathing spots, the absence of proper home surroundings have injurious effects on the Jewish child, to whom the simplest legal misdemeanors were in the past unknown. And what is true of the child is true of the adult. Whatever parasitic poverty may exist among Jews in the United States and in particular in New York, whatever percentage of criminals and vicious persons may have developed, the results are in the main due to the overcrowding and congestion, to which their poverty has subjected them.

How can an increase of these evils be averted? The remedy is plain and at the same time simple. The unfortunates, whom poverty and oppression have thrown together in such close proximity and who are compelled to live under such unnatural conditions, must be given the opportunity to settle in localities where ample room will be given for normal, physical, intellectual and moral growth. In New York, with characteristic insight, many are realizing the impossibility of full development in their present restricted environment and are taking up residence in the less settled outlying section of the city. There is no doubt that the improvement in transportation facilities, resulting from subways and tunnels, will considerably diminish the population of the East Side. To effect large results, some comprehensive scheme is necessary to relieve the congestion and to prevent the possibility of a recurrence of this congestion.

So far as the dependent Jewish classes are concerned, no scheme of philanthropy that can be introduced into the congested Jewish quarter of New York City can be more than palliative, that will permit of a continued increase in the number of residents of that section. More hospitals may be built in the city, more orphan asylums be endowed, settlements and neighborhood work of all 
kinds be organized and double and even treble the amount of money be spent in direct relief,-all these agencies can be only remedial in nature. They are not distinctly curative. All of them, to use the words of Miss Richmond, merely tide over the sufferer into the "miseries of next week." The causes which underlie the Jewish dependency as found in large cities are fundamental, and relief, to be permanent and preventive, must strike deep enough to reach the roots. An increase in institutions and agencies working under the existing conditions may, if anything, increase the number of applicants for assistance. There is no doubt that the presence of relief organizations, orphanages, etc., in a community, tend to weaken the moral responsibility of many a wage-earner through the consciousness that if he shirks his obligations to his family, society will assume them.

For this reason scientific Jewish philanthropy must develop along the lines of placing those who are now dependent and those who may become dependent, in such economic conditions that they may become independent. They must be located in communities and in such surroundings where industrial competition is not so fierce, that they cannot, even with the best of effort, earn living wages; where it will not be necessary for relief organizations to expend a greater portion of their energy in supplementing insufficient earnings; where housing and living conditions are not of such a kind as to aggravate the trouble instead of improving it; where the wageearner may have a chance to rear a home in the true sense of the word, to educate his children, to breathe fresh air and to live under sound sanitary conditions. There is one way to accomplish the above,-by the removal of large bodies of wage-earners with their families to other cities, and in particular towns throughout the United States.

Two years ago the Jewish Agricultural and Induscrial Aid Society of New York City undertook to distribute Jewish residents of New York City, who were willing to go, to other places in the United States, where work had previously been found for them. In the first year the society sent out $I, 800$ persons, in the second year 3,200 persons. During its present fiscal year, beginning January $I, 1903$, it has sent out $i, 400$ individuals and its work is constantly increasing. The plan of the society is to find industrial positions anywhere in the United States and having found them, 
to obtain individuals able to fill them from New York and other large cities like Philadelphia, Chicago and Boston. In order to carry on the work as effectively as possible, the society co-operates with the Independent Order B'nai B'rith, which has lodges distributed throughout many of the smaller towns and communities in the United States, and with the benevolent organizations and societies represented in the National Conference of Jewish Charities. It has an office in New York City known as the Industrial Removal office, which is the centre of the activities of the society. From here all applicants who desire to leave the city are sent away, provided with the necessary transportation and with the guarantee that provision will be made for them at their destination until such time as they become full-fledged wage-earners. Should conditions require it, it is not uncommon for the society to send the wage-earner in advance and to make provision for the care of the family remaining here through the United Hebrew Charities. As soon as the society hears from its correspondent that the wage-earner is in a position to care for his family the latter is sent on and a reunion of the family accomplished.

The value of such a movement as this cannot be over-estimated. The United States still has possibilities for thousands and even hundreds of thousands of new immigrants. There are still vast tracts of territory unexplored and which in time will offer excellent opportunity for new settlers. Following out this thought, the organization above mentioned distributes families to points as far south as E1 Paso, Texas, as far west as California, and as far north as Winnipeg. In fact no section of the United States has been ignored where it is possible to obtain work, nor has the employment sought been confined to any particular trades. All classes of laborers have been sent away, both skilled and unskilled. Aside from the fact that such a scheme as this will in time remove thousands from the congested centres of the large cities, its value for the future, however, lies in the fact that with each family sent away from New York City, or from Philadelphia, or from Boston, a new nucleus has been formed for the immigrant who may come in the next ten or twenty years. At present 70 per cent of arriving. Jewish immigrants remain in the city of New York. The reason for this is obvious. The man who emigrates to the United States goes by preference to that place where he has either relatives or friends, or to the destina- 
tion for which in many instances relatives have provided him and his family with the necessary transportation. So far as the immigrant himself is concerned, it matters little with him whether he goes to New York or to Saginaw; what he asks is an opportunity to earn his living for himself and his family. If 70 per cent of the Jewish immigrants remain in New York City it is because practically all of the immigrants of the last twenty years remained here. With the new nuclei and the new foci that are being formed in all sections of the United States through the movement inaugurated by the Jewish Agricultural and Industrial Aid Society, there is every likelihood that the percentage of Jewish immigrants remaining in New York will be decreased year by year. Finally, under the conditions existing in other communities, the Jews will again be able to renew the home life which is characteristic of them. Granted the opportunity to earn a living, to live decently in the sight of men, there need be no fear of an increase of Jewish dependency. In time the seaboard cities will be but stopping-places en route. In time there will be built up throughout the length and breadth of the United States, Jewish communities whose least concern and least expense will be the care of the dependent and poverty-stricken in their midst.

Uniled Hebrew Charities, New York City.

Lee K. Frankel. 